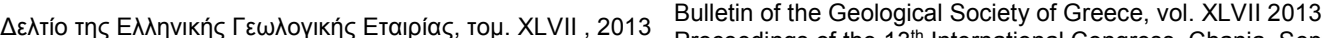
Proceedings of the $13^{\text {th }}$ International Congress, Chania, Sept.

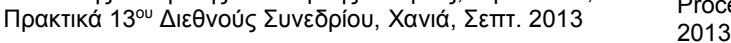

\title{
FLOOD RECONSTRUCTION USING BOTANICAL EVIDENCE IN RAPENTOSA CATCHMENT, IN MARATHON, GREECE
}

\author{
Diakakis M. ${ }^{1}$ \\ ${ }^{I}$ National and Kapodistrian University of Athens, Faculty of Geology and Geoenvironment, \\ 15784,Zografou, Athens, Greece,Email: diakakism@geol.uoa.gr
}

\begin{abstract}
Botanical evidence has been used in the past for flash flood analysis, especially when instrumental data were scarce. This work focuses on the use of such evidence as a tool to study flash flood phenomena in Rapentosa torrent, in Marathon, Greece. To this aim, impact scars induced during past flood events on trees along the torrent, were considered water stage indicators and were used to determine discharge magnitude of these flow episodes. Samples extracted from the scarred specimens with the aid of an increment borer, were used to date these impacts wounds. 1-D hydraulic modeling was used to provide a reconstruction of the highest-discharge event, while results were cross-examined with historical damages to verify the outcome of the analysis. Analysis showed a total of 22 impact wounds along the torrent indicating discharge values between $17.1 \mathrm{~m}^{3} / \mathrm{s}$ and $84.9 \mathrm{~m}^{3} / \mathrm{s}$ during past flow episodes. Three flash flood events were identified in 1996, 1998 and 2001. Hydraulic modeling of the 2001 event, which presented the highest flow values, illustrated its extent and water depth across the floodplain, presenting good correlation with the available documentary evidence.
\end{abstract}

Key words: Dendrochronology, Dendromorphology, Flood hazard, Marathonas, Flood reconstruction.

\section{Пєрí $\eta \psi \eta$}

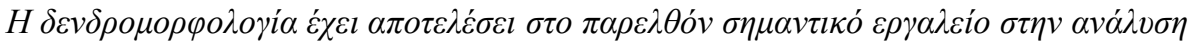

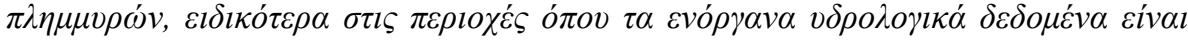

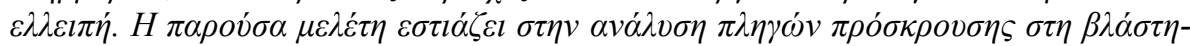

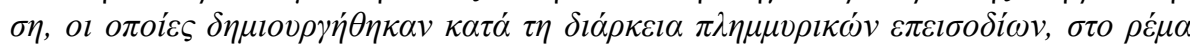

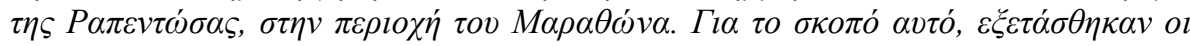

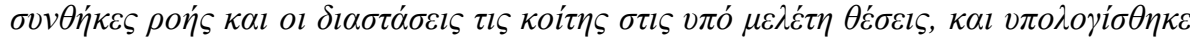

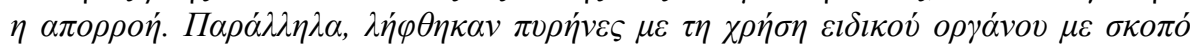

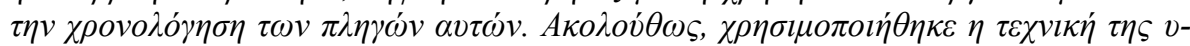

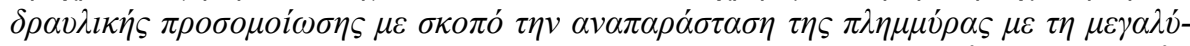

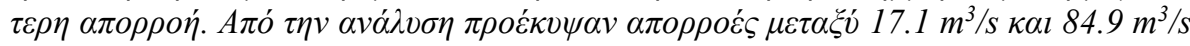

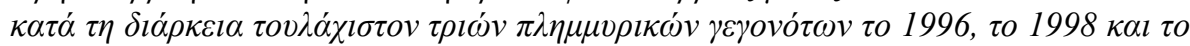

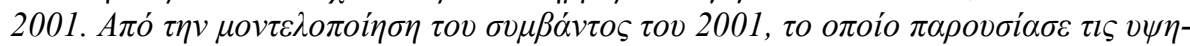

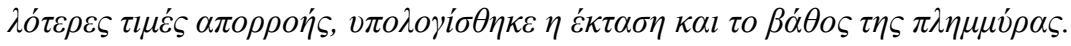

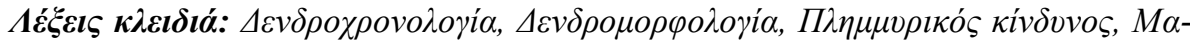
$\rho \alpha \theta \dot{v} v \alpha$.

$\underline{\text { XLVII, No } 3-1388}$ 


\section{Introduction}

The analysis of botanical evidence is an established scientific tool in natural hazards research (Butler et al., 1987, Stoffel and Bollschweiler, 2008, Stoffel et al., 2010) used to study a range of geological and hydrometeorological phenomena, such as debris flows (Hupp, 1984), wildfires (McBride, 1983, Grissino-Mayer, 2010), earthquakes (Bekker, 2010), landslides (Hupp, 1983, Stoffel and Perret, 2006) and floods (Gottesfeld, 1996, Zielonka et al., 2008, George, 2010). In the field of flood risk analysis, especially in the case of ungauged catchments, dendromorphology has been proved a useful and increasingly reliable approach (Stoffel and Bollschweiler, 2008, RuizVillanueva et al., 2010). One of the first descriptions of the impact of flooding on vegetation comes from Sigafoos (1964). Since then, several works have studied various disturbances of vegetation as source of information on past hydrologic episodes (Loomans, 1993, Ruiz-Villanueva et al., 2010). Scars caused on the stem of trees growing in channel banks, most likely formed by impact with woody debris and stones transported during intense flow episodes (Gottesfeld, 1996), have been used to identify floods, to examine raised water levels (Zielonka et al., 2008, George, 2010) and to date these events by tree-ring analysis (Ruiz-Villanueva et al., 2010).

Based on this principle several authors have exploited botanical evidence to estimate discharge in a single event or a series of floods (Jarrett, 1990, Gottesfeld, 1996, George, 2010), to reconstruct physical characteristics of flow (Loomans 1993, Tardif and Bergeron, 1997), to enrich flooding history and instrumental records (Yanoksy and Jarrett, 2002, Bollschweiler et al. 2011), to identify extreme floods (George and Nielsen, 2000), to estimate flood frequency (Hupp 1984) and to understand geomorphic processes of a river and their evolution (Baker 1994, Bollschweiler et al. 2011). Dendrochronology and dendromorphology have been used in conjunction with other hydrologic and hydraulic techniques to reconstruct and visualize characteristics of past flow episodes (Ballesteros et al. 2010).

Given the fact that flash flood analysis in ephemeral streams, in Greece, poses a significant challenge due to lack of instrumental data, this work analyses vegetation evidence along Rapenotsa catchment, in an effort to examine the applicability of the approach and improve our understanding on flood processes in the area, in terms of flood discharge and flood extent.

\section{Study Area}

The work carried out in this paper was conducted in Rapentosa catchment, in Attica, Greece, approximately $25 \mathrm{~km}$ northeast of the city of Athens (Figure 1). Rapentosa is an ephemeral mountain torrent with a basin area of 37.5 sq. km. draining the north slopes of Penteli Mt. At the last part of its course the torrent crosses Marathon plain, a fairly flat area dominated by agricultural land and the small settlements of Vranas and Tymvos. Directly upstream from the plain, which consists of Holocene alluvial deposits, the torrent passes through Mesozoic bedrock (mainly marble) forming a steep and narrow gorge.

The plain has been subject to flash flood phenomena several times in the past, claiming at least one life in 1980 (Diakakis 2010). According to historical evidence analyzed by Diakakis (2010) at least 13 distinct flash flooding events can be identified in 1805, 1959, 1980, 1987, 1988, 1996, 1998, 1999, 2001, 2003 and two in 2005. Examination of local wildfire history showed that three major forest fires have occurred in the area in 1995, 1998 and 2009 (Xanthopoulos 2002, Amiridis et al. 2012), leading, according to reports, to debris-laden river flows and increased amounts of sediments and vegetation fragments deposited across the plain and in the sea (Diakakis 2010).

This study was conducted in the $2730 \mathrm{~m}$ long section of the stream flowing through the gorge where dense coniferous vegetation is developed along the narrow riverbed and the banks of the torrent (Figure 1c). 


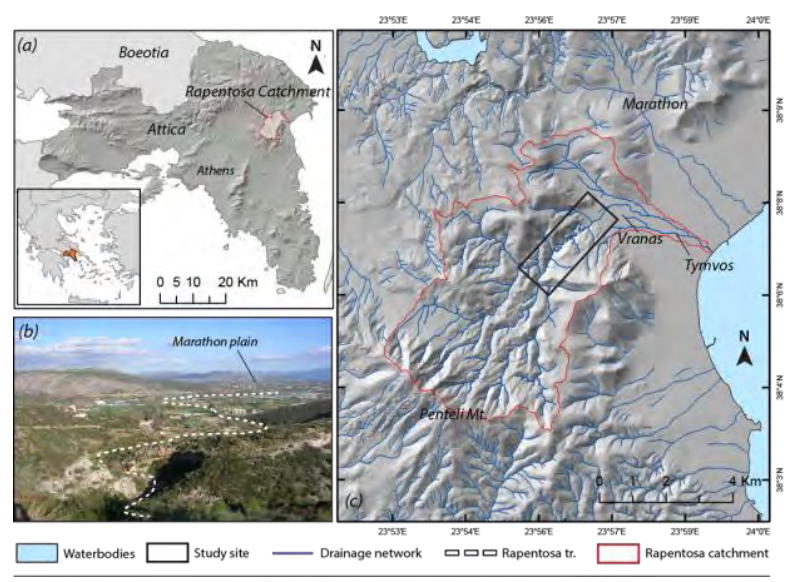

Figure 1 - (a) Location of the study area, (b) view of Rapentosa torrent flowing into Marathon plain (towards Northeast) and (c) overview of the Rapentosa drainage network and the study site.

\section{Materials and Methods}

The work carried out in this study can be divided into five main parts, namely: (i) field identification and mapping of flood-induced scars, (ii) recording of flow conditions and channel dimension at these locations, (iii) discharge calculations, (iv) core sampling and dating of scars and (v) 1-D modeling of highest calculated flood discharge.

\subsection{Field Survey}

The study started with field survey of the channel and its banks aimed to identify and map floodinduced external disturbances on vegetation. Tree trunks growing on the banks along the stream were carefully inspected for the presence of scars and other stem injuries. The survey confirmed 22 different cases of abrasion injuries (scars) on tree trunks of the conifer species Pinus Halepensis (Figure 2), created by either vegetation debris or stones transported violently during flood episodes. The scars were thoroughly inspected, photographed, measured and mapped with the aid of GPS equipment (Figure 3).

\subsection{Recording Flow Conditions and Measuring Channel Dimensions}

Flow conditions at the location of each injury were documented in order to calculate the channel's roughness coefficient for each spot according to the Aldridge and Garrett (1973) methodology. The cross sectional area was inspected, photographed and compared to the Aldridge and Garrett (1973) and Arcement and Schneider (1984) standards regarding six different variables affecting flow roughness, that is: (i) the channel's degree of irregularity, (ii) the variations in channel cross section, (iii) the channel's obstructions to flow, (iv) the amount of vegetation and (v) the degree of meandering.

Roughness coefficient (n) was then calculated according to the Cowan's (1956) equation:

Equation 1 - Cowan's (1956) equation for calculation of roughness coefficient.

$$
n=\left(n_{b}+n_{1}+n_{2}+n_{3}+n_{4}\right) \cdot m .
$$

where $n_{b}$ is a base value of $n$ for a straight, uniform, smooth channel in natural materials, $n_{1}$ is a correction factor connected with the degree of the channel's irregularity, $\mathrm{n}_{2}$ is a variable connected with the variations in the channel's cross section, $\mathrm{n}_{3}$ is a factor connected with the effect of 
obstructions to flow, $\mathrm{n}_{4}$ is a factor connected with the amount of vegetation and $\mathrm{m}$ is a factor connected with the degree of meandering.

To calculate discharge of flow episodes detailed measurements of the channel cross sectional area and the wetted perimeter were carried out with the aid of laser rangefinders with an accuracy of $1.5 \mathrm{~mm}$. Two sets of measurements were carried out with the rangefinders and a third with typical measuring tape to assure accuracy. Following this step, simple geometry calculations were carried out to determine the two variables of the channel dimensions.

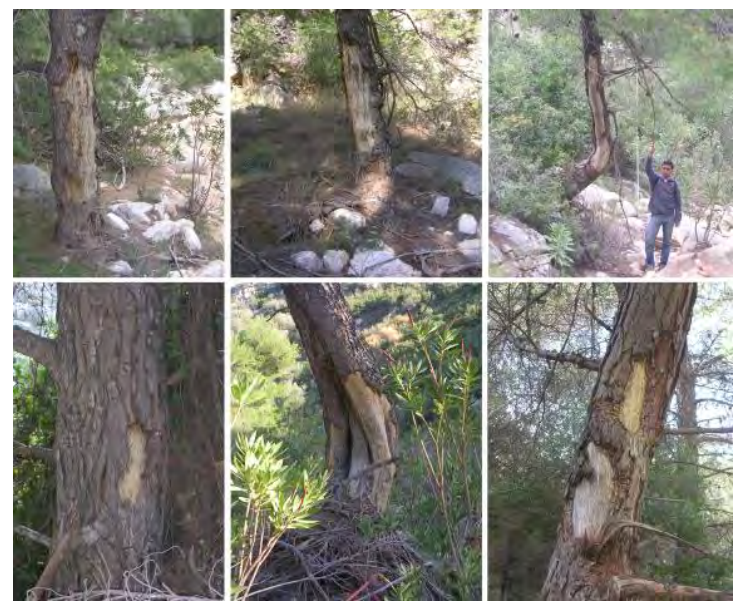

Figure 2 - Typical stem injuries (scars) along Rapentosa torrent banks.

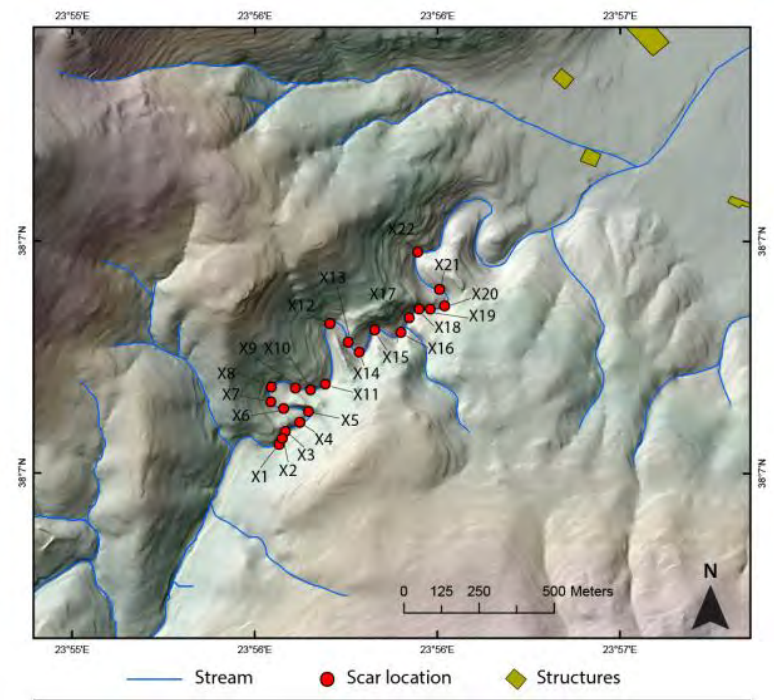

Figure 3 - Locations of abrasion scars identified in the study area.

\subsection{Discharge Calculations}

Given that injuries induced during flood episodes are considered water stage indicators, one can reconstruct discharge of a flow episode, using the Gauckler-Manning formula (Manning 1891):

Equation 2 - Gauckler-Manning formula

$$
Q=\frac{1}{n} \cdot A \cdot R^{2 / 3} \cdot S^{1 / 2}
$$


where $\mathrm{Q}$ is the flow discharge in $\mathrm{m}^{3} / \mathrm{s}, \mathrm{n}$ is the roughness coefficient, $\mathrm{A}$ is the cross sectional area in $\mathrm{m}^{2}, \mathrm{R}$ is the hydraulic radius in $\mathrm{m}, \mathrm{S}$ is the hydraulic slope. The hydraulic radius derives from the ratio of the cross sectional area (A) in $\mathrm{m}^{2}$, to the wetter perimeter of the channel (P) in $\mathrm{m}$.

\subsection{Injury Dating}

In order to determine the date of the injury, samples were extracted using a Haglof type increment borer of 16". Each tree specimen was sampled twice according to Barrett and Arno (1988) faceboring procedures for single scarred trees (Figure 4). After collection, cores were dried and sanded (surfaced) for ring analysis. Analysis was carried out using a 40x microscope and succeeded to determine the age of injury in 9 out of 22 samples.

\subsection{Hydraulic Modelling}

Hydraulic modeling was carried out to determine the extent of inundation and flow depth of the maximum discharge episode determined in prior steps of the methodology. To this aim, HEC-RAS model (HEC 2002) was used to simulate river flow downstream of the study site. Geometry of the channel and the floodplain was based on 1:5000 scale maps with $1 \mathrm{~m}$ contours and accurate measurements of the channel dimensions in 30-meter intervals with the technique described in 3.2. The whole model was built and run in a GIS interface.

\subsection{Uncertainties}

One source of uncertainty is connected with the fact that the state of vegetation affecting flow conditions at the time of each flood could not be accurately known. For this reason today's flow conditions were used in discharge calculations. With regard to the channel dimensions it is consider safe to assume that channel measurements are the same because its bedrock nature wouldn't allow significant changes in a few years time. In addition, several of tree specimens were partly destroyed by a wildfire in August 2009 and therefore dating of some of the injuries as mentioned in 3.4 was impossible.

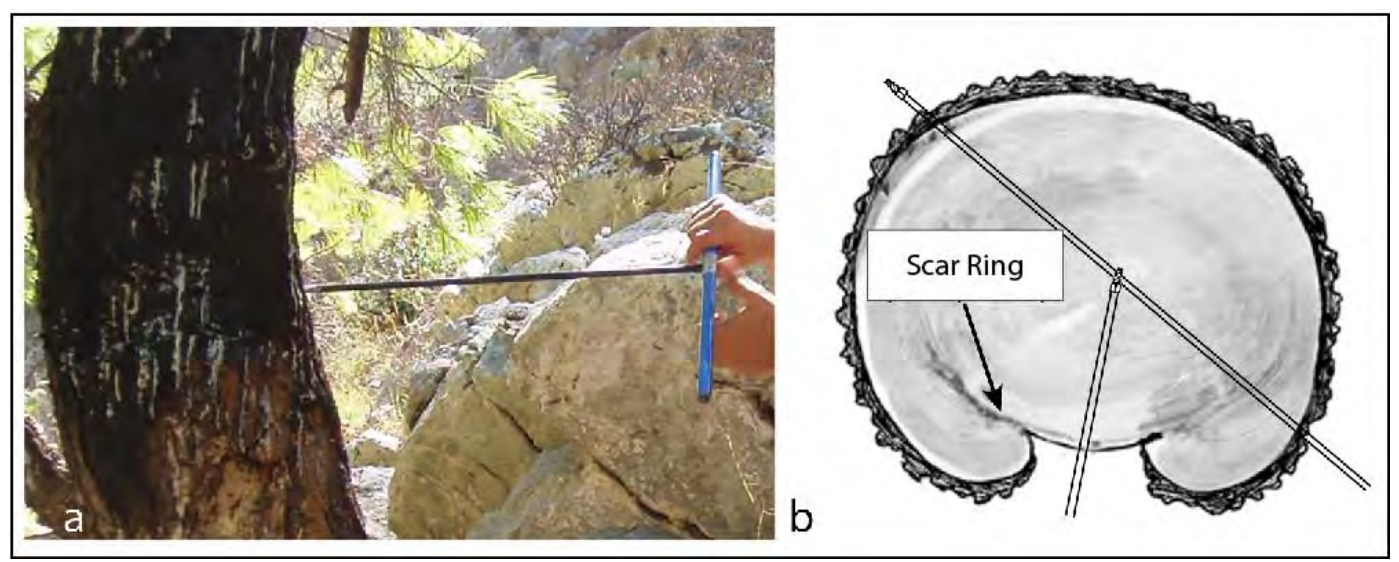

Figure 4 - Extracting samples using an increment borer (a), by a specific sampling approach illustrated on a schematic cross section of a tree trunk (b).

\section{Results and Discussion}

Discharge values indicated by each flood scar were calculated with the use of Gauckler-Manning formula between $17.1 \mathrm{~m}^{3} / \mathrm{s}$, and $84.9 \mathrm{~m}^{3} / \mathrm{s}$ (Table 1). 
Table 1 - Calculation of discharge (Q) for each impact location based on Manning formula and according to the channel parameters.

\begin{tabular}{|c|c|c|c|c|c|}
\hline $\begin{array}{l}\text { Location } \\
\text { Name }\end{array}$ & $A\left(m^{2}\right)$ & $\mathbf{P}(\mathbf{m})$ & $\mathbf{S}(\mathbf{m} / \mathbf{m})$ & $\mathbf{n}$ & $\mathrm{Q}\left(\mathrm{m}^{3} / \mathrm{s}\right)$ \\
\hline $\mathrm{X} 1$ & 11.1 & 15 & 0.04 & 0.128 & 14.3 \\
\hline $\mathrm{X} 2$ & \multicolumn{5}{|c|}{$\begin{array}{l}\text { Speciment destroyed completely during the course of research, due to a } \\
\text { wildfire }\end{array}$} \\
\hline X3 & 25.3 & 17 & 0.0349 & 0.143 & 42.9 \\
\hline $\mathrm{X} 4$ & \multicolumn{5}{|c|}{$\begin{array}{l}\text { Speciment destroyed completely during the course of research, due to a } \\
\text { wildfire }\end{array}$} \\
\hline X5 & 21.9 & 14.7 & 0.0305 & 0.119 & 41.9 \\
\hline X6 & 28.6 & 23.1 & 0.03143 & 0.079 & 74.2 \\
\hline $\mathrm{X7}$ & 25.7 & 22.9 & 0.0325 & 0.064 & 78.1 \\
\hline $\mathrm{X} 8$ & 25.1 & 19.5 & 0.0325 & 0.093 & 57.5 \\
\hline X9 & 19.1 & 20.2 & 0.0278 & 0.09 & 34.1 \\
\hline $\mathrm{X} 10$ & \multicolumn{5}{|c|}{$\begin{array}{l}\text { Speciment destroyed completely during the course of research, due to a } \\
\text { wildfire }\end{array}$} \\
\hline X11 & 24.3 & 18 & 0.0186 & 0.081 & 50.1 \\
\hline $\mathrm{X} 12$ & 14.4 & 14.1 & 0.0186 & 0.0736 & 26.9 \\
\hline $\mathrm{X} 13$ & 26.3 & 15.4 & 0.044 & 0.113 & 69.5 \\
\hline X14 & 23.3 & 20.1 & 0.0494 & 0.071 & 80.4 \\
\hline $\mathrm{X} 15$ & 19.8 & 23 & 0.032 & 0.059 & 54.3 \\
\hline $\mathrm{X} 16$ & 20.4 & 20 & 0.0571 & 0.058 & 84.9 \\
\hline $\mathrm{X} 17$ & 20.8 & 23.5 & 0.0303 & 0.097 & 34.6 \\
\hline $\mathrm{X} 18$ & 20.6 & 15.7 & 0.0303 & 0.129 & 33.4 \\
\hline X19 & 15.7 & 13 & 0.0303 & 0.181 & 17.1 \\
\hline $\mathrm{X} 20$ & 29 & 19.9 & 0.036 & 0.13 & 54.5 \\
\hline $\mathrm{X} 21$ & 20.4 & 18.9 & 0.0421 & 0.144 & 30.5 \\
\hline X22 & 20.5 & 14.6 & 0.0415 & 0.083 & 63.2 \\
\hline
\end{tabular}

Tree-ring analysis lead to the determination of impact year, in 9 out of 22 samples identifying three distinct flow episodes in 1996, 1998 and 2001 (Figure 5).

Analysis showed that the 2001 event presented the highest calculated flow value $\left(84.9 \mathrm{~m}^{3} / \mathrm{s}\right)$ (Table 2), indicating for the first time in this ungauged catchment the magnitude of flood episodes locally. Based on this value and with the aid of hydraulic modeling the study was able to determine the extent of flooding across the Marathon plain, delineating in this way the active part of the floodplain and determining the human infrastructure that is developed in this floodsusceptible area (Figure 6). In addition, the simulation calculated and visualized the depth of floodwaters for the 2001 scenario. This information can be valuable to estimate damage cost of future flooding in the area. Both flood extent and depth data improve our knowledge on the local flooding problem and can be used to define a long term strategy for flood risk mitigation planning, by illustrating its priorities, by identifying the flood-susceptible areas and by quantifying the impact of flooding. For verification purposes simulation results were compared with 2001 flood damages showing good correlation.

XLVII, No $3-1393$ 


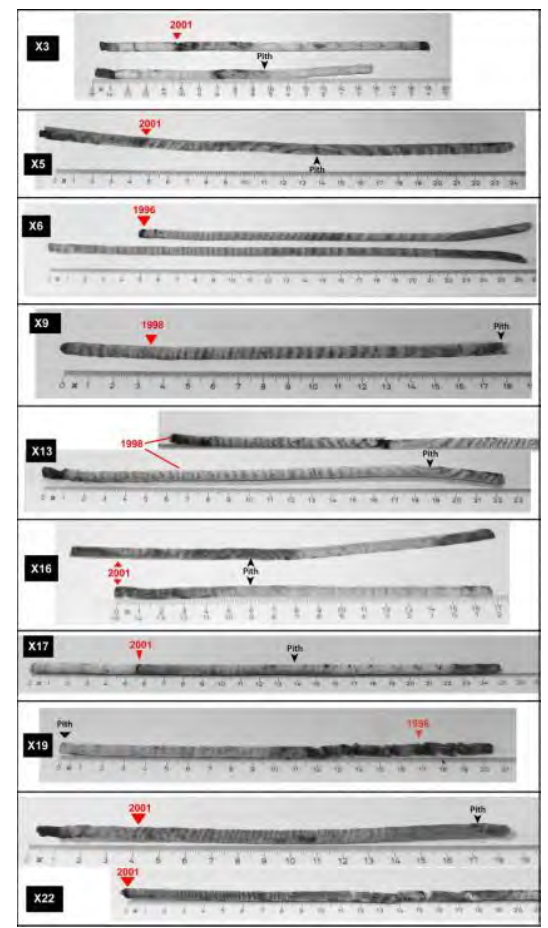

Figure 5 - Core samples extracted from scarred specimens in which determination of impact date was plausible. Impact year is appearing in red indicator, whereas scar codename appear in black rectangular in the left side of the image.

Table 2 - Date and discharge values indicated by 9 out of 22 impact scars.

\begin{tabular}{|c|c|c|}
\hline Impact location & Year of impact & Discharge values $\left(\mathbf{m}^{\mathbf{3}} / \mathbf{s}\right)$ \\
\hline $\mathrm{X} 6, \mathrm{X} 19$ & 1996 & $17.1-74.2$ \\
\hline $\mathrm{X} 9, \mathrm{X} 13$ & 1998 & $34.1-69.5$ \\
\hline $\mathrm{X} 3, \mathrm{X} 5, \mathrm{X} 16, \mathrm{X} 17, \mathrm{X} 22$ & 2001 & $34.6-84.9$ \\
\hline
\end{tabular}

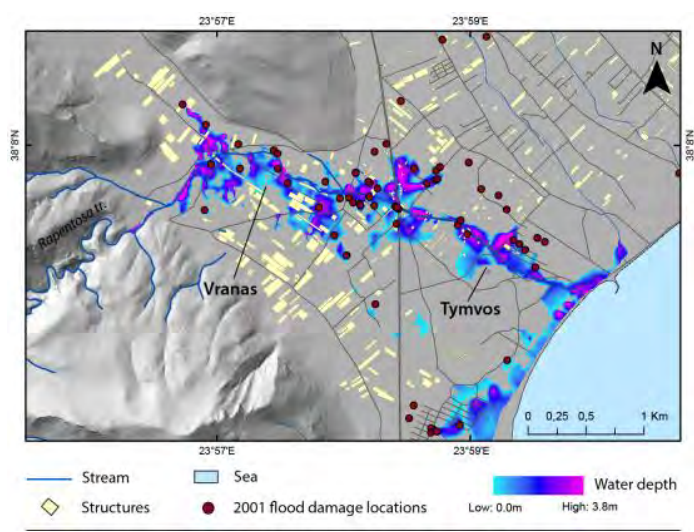

Figure 6 - Hydraulic simulation of 2001 flood discharge across Marathon floodplain showing water extent and depth, and the 2001 flood damage locations. 


\section{Conclusions}

This work examines a series of flood impact scars along the ungauged torrent of Rapentosa, near Marathon in Greece. Based on hydraulic conditions and channel dimensions, this study manages to calculate discharge values reaching up to $84.9 \mathrm{~m}^{3} / \mathrm{s}$ and identifies through tree-ring analysis at least three distinct flood events in 1996, 1998 and 2001. With the aid of hydraulic modelling, flood extent and water depth of the 2001 event are simulated and compared with historical flood damages, showing good correlation, verifying in this way the results of the analysis. The technique was proved to be a useful tool for determination of discharge values in ungauged catchments, delineation of the active floodplain and the physical characteristics of floodwaters as a basis for flood risk studies.

\section{Acknowledgments}

This work is dedicated with gratitude to the late Associate Professor of the National and Kapodistrian University of Athens, Ioannis Fountoulis, who always supported the author as an academic and as a friend. The author would like also to express his gratitude to Dr. Gavriil Xanthopoulos for offering his help and advice on the tree boring procedures and for lending equipment without which this research would not be completed. The author would also like to thank the friends and colleagues S. Mallis, P. Vamvakas, N. Papafakli, G. Glynos and K. Lazoglou for helping during fieldwork.

\section{References}

Acrement G.J. and Schneider V.R. 1984. Guide for selecting Manning's Roughness Coefficients for Natural Channels and Flood Plains, United States Geological Survey Water-supply Paper 2339, 67pp.

Aldridge B.N. and Garrett J.M. 1973. Roughness coefficients for stream channels in Arizona: U.S. Geological Survey Open-File Report, 87 pp.

Amiridisa V. Zerefosb C., Kazadzisd S., Gerasopoulos E., Eleftheratos K., Vrekoussis M., Stohl A., Mamouri R.E., Kokkalis P., Papayannis A., Eleftheriadis K., Diapouli E., Keramitsoglou I., Kontoes C., Kotroni V., Lagouvardos K., Marinou E., Giannakaki E., Kostopoulou E., Giannakopoulos C., Richter A., Burrows J.P. and Mihalopoulos N. 2012. Impact of the 2009 Attica wild fires on the air quality in urban Athens, Atmospheric Environment, 46, 536-544.

Baker V.R. 1994. Geomorphological understanding of floods, Geomorphology, 10, 139-156.

Ballesteros J.A., Eguibar M., Bodoque J.M., Diez-Herrero A., Stoffel M. and Gutierez-Perez I. 2010. Estimating flash flood discharge in an ungauged mountain catchment with 2D hydraulic models and dendrogeomorphic palaeostage indicators, Hydrological Processes, 25, 6, 970-979.

Barrett S.W. and Arno S.F. 1988. Increment-borer methods for determining fire history in coniferous forests, United States Department of Agriculture. General Technical Report INT-244. 20pp.

Bekker M.F. Tree rings and earthquakes, in: Stoffel M., Bollschweiller M., Butler D. R., Luckman, B. H. (eds), Tree rings and natural hazards. A state-of-the-art. 3-23, New York, Springer, 505pp.

Bollschweiller M., Stoffel M. and Schlappy R. 2011. Debris-flood reconstruction in a pre-alpine catchment in Switzerland based on tree-ring records of coniferous and broadleaved trees, Geografiska Annaler: Series A, Physical Geography, 93, 1, 1-15.

Butler D.R., Malanson G.P. and Oelfke J.G. 1987. Tree-Ring analysis and natural hazard chronologies: minimum sample sizes and index values, The Professional Geographer, 39, 1, 41-47.

Cowan W.L. 1956. Estimating hydraulic roughness coefficients, Agricultural Engineering, 37, 7, 473-475.

$\underline{\text { XLVII, No } 3-1395}$ 
Diakakis M. 2010. Flood history analysis and its contribution to flood hazard assessment: the case of Marathonas, Greece, Bull. Geol. Soc. Greece, 43, 1323-1334.

George S.St. 2010. Dendrohydrology and Extreme Floods Along the Red River, Canada, in: Stoffel M., Bollschweiller M., Butler D.R. and Luckman B.H. (eds), Tree rings and natural hazards. A state-of-the-art, 3-23, New York, Springer, 505pp.

George S.St. and Nielsen E. 2000. Signatures of high-magnitude 19th-century floods in Quercus macrocarpa tree rings along the Red River, Manitorba, Canada, Geology, 28, 10, 899-902.

Gottesfeld A.S. 1996. British Columbia flood scars: maximum flood-stage indicators, Geomorphology, 14, 319-325.

Grissino-Mayer H.D. 2010. Wildfire Hazard and the Role of Tree-Ring Research, in: Stoffel, M., Bollschweiller, M., Butler, D. R., Luckman, B. H. (eds), Tree rings and natural hazards. A state-of-the-art. 3-23, New York, Springer, 505pp.

HEC 2002. HEC-RAS River analysis system. Hydraulic Reference Manual Version 3.1. Hydrologic Engineering Center, US Army Corps of Engineers.

Hupp C.R. 1983. Geo-botanical evidence of late Quaternary mass wasting in block field areas of Virginia, Earth Surface Processes and Landforms, 8, 439-450.

Hupp C.R. 1984. Dendrogeomorphic evidence of debris flow frequency and magnitude at Mount Shasta, California, Environ. Geol. Water Sci., 6, 2, 121-128.

Jarrett R.D. 1990. Paleohydrology used to define the spatial occurrence of floods, Geomorphology, 3, 81-95.

Loomans S.A. 1993. Flood reconstruction in Southern Illinois using tree rings, MSc Thesis, University of Illinois at Urbana-Champaign. 87pp.

Manning R. 1891. On the flow of water in open channels and pipes, Inst. Civ. Eng. Ireland Trans. 20, 161-207.

McBride J.R. 1983. Analysis of the tree rings and fire scars to establish fire history, Tree-ring Bull., 43, 51-67.

Ruiz-Villanueva V., Diez-Herrero A., Stoffel M., Bollschweiller M. and Ballesteros J.A. 2010. Dendrogeomorphic analysis of flash floods in a small ungauged mountain catchment (Central Spain), Geomorphology, 118, 383-392.

Sigafoos R.S. 1964. Botanical evidence of floods and flood-plain deposition, United States Geological Survey Professional Paper, 485-A, 35 pp.

Stoffel M. and Bollschweiller M. 2008. Tree-ring analysis in natural hazards research-an overview, Nat. Hazards Earth Syst. Sci., 8, 187-202.

Stoffel M., Bollschweiller M. Butler D.R. and Luckman B.H. 2010. Tree rings and natural hazards: An introduction, in: Stoffel, M., Bollschweiller, M., Butler, D. R., Luckman, B. H. (eds), Tree rings and natural hazards. A state-of-the-art. 3-23, New York, Springer, 505pp.

Stoffel M. and Perret S. 2006. Reconstructing past rockfall activity with tree rings: some methodological considerations, Dendrochronologia, 24, 1-15.

Tardif J. and Bergeron Y. 1997. Ice flood history reconstructed with tree-rings from the southern boreal forest limit, western Quebec, Holocene, 7, 291-300.

Xanthopoulos G. 2002. The forest fires of 1995 and 1998 on Penteli Mountain, Proceedings of the International Workshop on "Improving Dispatching for Forest Fire Control". December 68, 2001. Chania, Crete, Greece. G. Xanthopoulos, (ed) pp. 85-94, Mediterranean Agronomic Institute of Chania, Chania, Crete, Greece. $162 \mathrm{p}$.

Yanosky T.M. and Jarrett R.D. 2002 Dendrochronologic evidence for the frequency and magnitude of paleofloods, Water Science and Application, 5, 77-89.

Zielonka T., Holeksa J. and Ciapala S. 2008. A reconstruction of flood events using scarred trees in the Tatra Mountains, Poland, Dendrochronologia, 26, 173-183. 